\title{
Transatlantica
}

Revue d'études américaines. American Studies Journal

\section{There's No Place like (Fun) Home}

Paris, January 24 2007, and Tours, January 252007

\section{Juliette Cherbuliez}

\section{(2) OpenEdition}

Journals

\section{Édition électronique}

URL : http://journals.openedition.org/transatlantica/1227

DOI : 10.4000/transatlantica. 1227

ISSN : $1765-2766$

Éditeur

AFEA

Référence électronique

Juliette Cherbuliez, « There's No Place like (Fun) Home », Transatlantica [En ligne], 1 | 2007, mis en ligne le 23 mai 2007, consulté le 29 avril 2021. URL : http://journals.openedition.org/transatlantica/1227 ; DOI : https://doi.org/10.4000/transatlantica.1227

Ce document a été généré automatiquement le 29 avril 2021.

\section{(c) (i)}

Transatlantica - Revue d'études américaines est mis à disposition selon les termes de la licence Creative Commons Attribution - Pas d'Utilisation Commerciale - Pas de Modification 4.0 International. 


\title{
There's No Place like (Fun) Home
}

Paris, January 24 2007, and Tours, January 252007

\author{
Juliette Cherbuliez
}

1 What best describes the status of American Studies in today's France? Toni Morrison inviting French slammers to declaim their poetry at the Louvre comes to mind immediately. The image of the United States' foremost Black writer legitimating traditionally marginalized popular verse, and in the bastion of European culture that is France's premier museum to boot, sparks a series of felicitous paradoxes: the postemancipation of the colonies comes to the post-colonial, the high brow white man's museum welcomes one of the most widely-appreciated Black American novelists of our times, and of course, the exception française extends an exceptional welcome for the complexity and diversity of the American experience, through one of its doyennes.

2 There's nothing exceptional about this portrait of the impact of US culture on French culture, or on what it means to be a major international institution today. Serious considerations of contemporary American culture and arts are now the norm at major Parisian museums. (This is true even at the Louvre: Toni Morrison's five-week stint followed another Franco-American encounter a year ago and covered recently in this journal, "De la démocratie en Amérique: Arts, sciences et politique 1776-1865," which itself anticipated the opening of the new American wing at the Museum.) Indeed, these kinds of events are what major institutions are especially good at: documenting and celebrating that which the public already considers as its international heritage.

3 But what about the future of American culture? It was not at the Louvre, but at the Institute Charles V/Université Paris 7-Jussieu's UFR d'Études Anglophones, in the Marais, that important inquiry into the complexity of American culture was held. There, on 24 January, the GRAAT (Université François Rabelais-Tours), organized the first ever academic conference on Alison Bechdel. Bechdel, known in feminist and lesbian circles for the past 25 years for her comic strip Dykes To Watch Out For, joined the colloquium to speak about her newest publication, the graphic novel Fun Home (Houghton-Mifflin, 2006; Denoël 2006). A conference was organized at Tours the following day. The event demonstrated that the French-American encounter produces 
original, timely research that is not only relevant to both cultures but perhaps even revelatory of the direction French and American literature and art is taking.

4 Fun Home: A Family tragicomic traces the author's childhood in small-town Pennsylvania with her family in a Gothic-revival house (dubbed ironically "Fun Home" by its younger inhabitants) that will remind American readers of the proto-Goth house in the TV comedy series The Munsters, or perhaps of Charles Addams's Addams Family. Bechdel's Fun Home, however, is truly tragicomic, with all the contradictions and intricacies that the genre implies. Weaving images and texts through her reconstructed memories, Bechdel comes to terms with her father in particular, a school teacher, part-time funeral-home director, fanatical home decorator, and closeted homosexual, who died in 1980 at age 44, just after Bechdel's own coming out.

5 Fun Home represents a turn in American publishing. At least in its production and reception, Fun Home is a surprisingly mainstream novel. When it was published by Houghton-Mifflin in 2006, it was their first graphic novel ever. When it won Time magazine's 2006 "Book of the Year" award, it confirmed the importance of the memoir novel in American culture today, but through a decidedly unpuritanical choice of childhood stories.

6 Fun Home is also a turn for Bechdel, as her first publication in the booming graphicnovel genre and a certain turn in tone, style, and creative process from her comic strip. The adult comic is one element that French and American culture share-a love of fairly sophisticated illustrated stories, often political in theme. But Bechdel's newest work is distinctive within the genre, especially because of her role as one of the major lesbian cartoonists of the past twenty years. Bechdel has stated, "I wouldn't identify myself as post-gay, but I would say that I'm tired of having to be a lesbianof having to be a lesbian cartoonist" $\left(2004^{1}\right)$. Nevertheless, for colloquium organizer Hélène Tison, the question of sexuality remains an important motor for academic inquiries into Bechdel's work: "Organizing these conferences seemed important to me for a number of reasons. First, Alison Bechdel is doubly marginal, as a comic-book writer of lesbian content. This marginal position affords her a pretty unique perspective, which influences the comic strip Dykes to Watch Out For as much as her graphic memoir Fun Home."

7 The one-day colloquium at Charles $\mathrm{V}$ acknowledged both the centrality of homosexuality to Bechdel's work and its necessary periphery, because in Fun Home the question of sexual identity is addressed first and foremost through a web of other issues: family history, opacity and silence, love of literature and art, the space of the home itself. Indeed, papers presented acknowledged the increasing complexity of Bechdel's work by focusing largely on the literary and aesthetic qualities of Fun Home (and to a lesser extent of Dykes to Watch Out For).

8 After a welcome from Department Chair Robert Mankin, Hélène Tison opened the colloquium with a short presentation on Bechdel's newest book and on the goals of the two colloquia. Bechdel gave a presentation on the genesis of the book. In contrast with Fun Home's autobiographical thrust, Bechdel concentrated not on the story but on the very technical ways in which she created it. A self-avowed obsessive archivist, Bechdel applied this same attention to the creation of each panel. She posed for and photographed recreations of each frame, in order to later redraw the scene. This technique is a recreation and reappropriation of the book's other genesis-her 
discovery of certain photos that was a clue to her father's homosexuality and led her to reconsider, and rewrite, her own life.

With the author present, academics from Charles V, Jussieu and Nanterre then proposed several interventions with what the author herself called "delightfully academic titles," (see blog) on a diversity of approaches to Bechdel's work. In his presentation on "Double Trajectories: Crossing Lines in Fun Home," Karim Chabani called the novel a "study in skepticism" that nevertheless stages an "aesthetic family reunion... through the circulation of words and images." He went on to suggest how the appearance and reappearance of photos, books, doubled images, etc., characterizes the novel and defines the kinds of intimacies and encounters between the protagonist and members of her family. In Sara Thornton's "Literary Spaces in Alison Bechdel: Proust, Dickens and the 'Fun Home," Bechdel's images of the house, her engagement with her memories and the possibility of recreating them, and especially the evocation of her father's love of literature, were the impetus for a comparison to similar themes and spaces in Dickens and Proust. In "Image as Paratext in Alison Bechdel's Fun Home," Agnès Muller suggested a method for reading the relationship between image and text. Investigating Genette's concept of the paratext as it might relate to other mixed-media artistic works such as opera, and also to the particular use Bechdel makes of spaces around the images, Muller demonstrated how the use of space in Fun Home helped to convey aspects of communication that elude language, such as silences. Last, Crémieux's powerpoint presentation demonstrated, through an analysis of the cover art of Dykes to Watch Out For, how perceptions of this ground-breaking series have changed. (All presentations are available for download on the GRAAT website) For Tison, echoing Bechdel's own words on Dykes to Watch Out For, the comic strip is "part soap opera, part social criticism... The 25 years covered in this strip reflect an original and highly relevant portrait of the US, especially with regard to its LGBT and queer community." In the series re-edition, the cover art has been "mainstreamed," its lesbian subtexts rendered arguably less flagrant, and its serial quality more apparent through unifying graphic elements. While the series loses some of the eclectic qualities that a comic book compilation has, when published for the first time, it also reflects the changes in queer culture's relationship to dominant heterosexual culture, especially the institutionalization and even acceptance of the queer voice.

It should be no surprise that the majority of the interventions refused either a purely literary or a purely visual metaphor for reading Bechdel, given the relationship between word and image in comics and graphic novels. Terms such as "reading between the lines," "convergences," and "paratext" reflect this rich relationship in Fun Home between the mixed media of text and image. On the surface, one might argue that this is true of every memoir, which necessarily addresses the vicious cycle of remembering, reconstructing, and recreating that defines the practice of self-made memory autobiography is based on. By its insistence on the visual, on the mimetic, on the interstices between image and text, and on memory as a visual element, however, the colloquium revealed a particularity of Bechdel's work: that this "Sisyphean circle" (Fun Home 48), in which the art of memory rejoins the art of self-knowledge, is an obsessively material affair. Both word and image derive from objects and manipulations of objects: the Gothic house, the repeated references to books and photos, the importance of mirrors and doubling. Indeed, these analyses seemed to have anticipated Bechdel's demonstration of her meticulous and obsessive reconstruction of memories through an elaborate process that extends beyond most comic art: the 
construction of every frame from posed photos she took herself, the redrawing of maps and rewriting of letters by hand, the layering of water color over ink on a separate sheet, scanned in and minutely reworked on PhotoShop. If Bechdel's initial pursuit of herself began at an early age, with a premature "sort of epistemological crisis" (Fun Home 141) in which everything she wrote down as a child was followed by a tiny annotation of "I think," the way out of such a crisis is not to think or to rethink but to draw and to redraw. Fun Home, as the Charles V colloquium demonstrated, is a complex interrogation of the enduring materiality of our memories and ourselves.

11 Tison found both days very different and equally successful. Whereas the event at Charles V was generally a university event, the day at the Université François Rabelais in Tours included a mix of academics and high-school students. In both cases, the audience included people who had not read or even heard of Bechdel. And in each case the dynamic quality of Bechdel's presentations (along with, at Charles V, the diverse perspectives offered by the university presentations) inspired many questions from both audiences. For Tison, "The spontaneity and straight-forwardness of Alison Bechdel, the pleasure she takes in talking about her work, and her attentiveness toward her public, all allowed for a rich and warm exchange." And in turn, "She was delighted to participate in the first conference on her work-and even found it quite fun!"

One can only hope the GRAAT conference on Bechdel will become a tradition, since the author has apparently signed a contract for a second graphic novel, entitled Love Life: A Case Study. In any case, watch out for the next GRAAT event of this type, "Reading Thomas Pynchon's Latest Novel Against the Day", June 1 2007, at the Université François Rabelais in Tours.

13 (Chabani and Muller's talks were published in the March edition of GRAAT, along with a powerpoint of Crémieux's analysis of book-cover art from Dykes to Watch out For, and an article by Tison, originally given at Tours, on "Drag as Metaphor and the Quest for Meaning in Alison Bechdel's Fun Home: A Family Tragicomic." Readers will also find an interview with Bechdel and a video presentation of her talk at Tours).

\section{NOTES}

1. Interview by Rex Wockner with Alison Bechdel on Dykes To Watch Out For's 20th Birthday, August 2004, http://members.aol.com/wockner/alison.html

\section{INDEX}

Thèmes : Trans'Arts 
AUTEUR

JULIETTE CHERBULIEZ

University of Minnesota 